\title{
Weed Management in Pecans 1
}

\author{
Jeffrey G. Williamson²
}

The following table contains information on chemical weed control for pecans grown in Florida. Always read and follow all label directions carefully and exactly when applying any pesticide. Soil types and possible crop injury from herbicides vary greatly throughout Florida. Do not apply a herbicide to an inappropriate soil type even if the herbicide is labeled for that crop. See Table 1.

1. This document is HS95, one of a series of the Horticultural Sciences Department, Florida Cooperative Extension Service, Institute of Food and Agricultural Sciences, University of Florida. Original publication date: 1994. Revised: November, 2007. Please visit the EDIS Web site at http://edis.ifas.ufl.edu.

2. Jeffrey G. Williamson, professor, Horticultural Sciences Department, Cooperative Extension Service, Institute of Food and Agricultural Sciences, University of Florida, Gainesville, FL 32611.

The Institute of Food and Agricultural Sciences (IFAS) is an Equal Opportunity Institution authorized to provide research, educational information and other services only to individuals and institutions that function with non-discrimination with respect to race, creed, color, religion, age, disability, sex, sexual orientation, marital status, national origin, political opinions or affiliations. U.S. Department of Agriculture, Cooperative Extension Service, University of Florida, IFAS, Florida A. \& M. University Cooperative Extension Program, and Boards of County Commissioners Cooperating. Larry Arrington, Dean 
Table 1. Chemical weed control in pecans.

\begin{tabular}{|c|c|c|}
\hline \multicolumn{3}{|l|}{ Pre-emergence } \\
\hline $\begin{array}{l}\text { Common Name } \\
\text { (Trade name) }\end{array}$ & $\begin{array}{l}\text { Pounds active ingredient } \\
\text { per acre }\end{array}$ & Time of Application \\
\hline $\begin{array}{l}\text { Diuron } \\
\text { (Karmex) } 80 \text { WDG } \\
\text { (Diuron) } 80 \text { WDG } \\
\text { (Direx) } 4 \text { L }\end{array}$ & 1.6 to 3.2 & $\begin{array}{l}\text { Early spring before weeds emerge or during } \\
\text { early seedling stage of growth. }\end{array}$ \\
\hline \multicolumn{3}{|c|}{$\begin{array}{l}\text { Weeds Controlled and Remarks: Annual broadleaf weeds, annual grasses and perennial weed } \\
\text { seedlings. Trees must be established in orchard for at least } 3 \text { yrs. Rate used depends on soil texture and } \\
\text { organic matter content. Do not use on soil with less than } 0.5 \% \text { organic matter or on sands, loamy sands or } \\
\text { gravelly soils (see label). Do not use on eroded areas where subsoil or roots are exposed, nor on trees that } \\
\text { are diseased or lacking vigor. Moisture is required to activate chemical. Do not graze treated area. Only } 1 \\
\text { application per year. Contact action is enhanced by the addition of a surfactant. }\end{array}$} \\
\hline $\begin{array}{l}\text { Oryzalin } \\
\text { (Surflan) } 4 \text { AS }\end{array}$ & 2 to 4 & $\begin{array}{l}\text { Treat after the soil has settled following } \\
\text { transplanting but before spring weeds emerge. }\end{array}$ \\
\hline \multicolumn{3}{|c|}{$\begin{array}{l}\text { Weeds Controlled and Remarks: Annual grasses and broadleaf weeds. Existing vegetation should be } \\
\text { tilled prior to application or destroyed by a contact herbicide. A single } 1 / 2 \text { to } 1 \text { inch irrigation or rainfall is } \\
\text { needed to move surflan into the zone of weed seed germination. }\end{array}$} \\
\hline $\begin{array}{l}\text { Oyyfluorfen } \\
\text { (Galigan) 2E } \\
\text { (Goal 2XL) 2EC } \\
\text { (OxiFlo) 2EC } \\
\text { (GoalTender) 4E }\end{array}$ & 1.25 to 2 & $\begin{array}{l}\text { Do not treat newly planted trees until soil has } \\
\text { settled around roots do not apply within } 60 \\
\text { days of harvest. (see label for more details on } \\
\text { timing applications). }\end{array}$ \\
\hline \multicolumn{3}{|c|}{$\begin{array}{l}\text { Weeds Controlled and Remarks: Controls annual grasses and some broadleaf weeds. Effectiveness is } \\
\text { increased when adequate rainfall occurs within } 7 \text { days after application. }\end{array}$} \\
\hline $\begin{array}{l}\text { Simazine } \\
\text { (Princep, Simazine) } \\
\text { 4L, } 90 \text { WDG }\end{array}$ & 2 to 4 & $\begin{array}{l}\text { Apply before weeds emerge or after removal } \\
\text { of growth. }\end{array}$ \\
\hline \multicolumn{3}{|c|}{$\begin{array}{l}\text { Weeds Controlled and Remarks: Controls certain annual grasses and broadleaf weeds. Trees must be } \\
\text { established at least } 2 \text { yrs in the orchard before application. Rate depends on soil texture. Do not use on } \\
\text { sand, loamy sand, or gravelly soils. Do not apply when nuts are on the ground. Do not allow animals to } \\
\text { graze treated areas. }\end{array}$} \\
\hline $\begin{array}{l}\text { Oryzalin } \\
\text { (Oryzalin, Surflan) } 4 A S \\
\quad+ \\
\text { Simazine } \\
\text { (Princep, Simazine) } 4 \mathrm{~L} \\
90 \text { WDG }\end{array}$ & $\begin{array}{c}2 \text { to } 4 \\
+ \\
2 \text { to } 4\end{array}$ & Refer to labels for detailed information. \\
\hline \multicolumn{3}{|c|}{$\begin{array}{l}\text { Weeds Controlled and Remarks: Controls broadleaf weeds and annual grass weeds. Refer to labels of } \\
\text { the respective products. }\end{array}$} \\
\hline
\end{tabular}


Table 1. Chemical weed control in pecans.

\begin{tabular}{|c|c|c|}
\hline \multicolumn{3}{|c|}{ Pre-emergence non-bearing only } \\
\hline $\begin{array}{l}\text { Common Name } \\
\text { (Trade name) }\end{array}$ & $\begin{array}{l}\text { Pounds active ingredient } \\
\text { per acre }\end{array}$ & Time of Application \\
\hline $\begin{array}{l}\text { Pendimethalin } \\
\left(\text { Prowl } \mathrm{H}_{2} \mathrm{O}\right) 4 \mathrm{AS}\end{array}$ & 2 to 4 & Nonbearing trees only. \\
\hline \multicolumn{3}{|c|}{$\begin{array}{l}\text { Weeds Controlled and Remarks: Controls annual grasses and some broadleafed weeds. Most effective } \\
\text { when adequate rainfall or irrigation is received within } 21 \text { days after application. Do not apply to newly } \\
\text { transplanted trees until soil has settled around roots. Apply spray directly to the ground beneath the trees. }\end{array}$} \\
\hline \multicolumn{3}{|l|}{ Post-emergence } \\
\hline $\begin{array}{l}\text { Common Name } \\
\text { (Trade name) }\end{array}$ & $\begin{array}{l}\text { Pounds active ingredient } \\
\text { per acre }\end{array}$ & Time of Application \\
\hline $\begin{array}{l}\text { Carfentrazone-ethyl } \\
\text { (Aim) 2EC }\end{array}$ & 0.008 to 0.031 & $\begin{array}{l}\text { Best results when applied to weeds that are in } \\
\text { the } 2 \text { - } 3 \text { leaf stage. }\end{array}$ \\
\hline
\end{tabular}

Weeds Controlled and Remarks: Apply with a minimum spray volume of $20 \mathrm{gpa}$. Do not allow contact of spray with green bark, or desirable foliage flowers or fruit of the crop. Do not harvest within 7 days of application. Use a nonionic surfactant or crop oil concentrate (see label).

\begin{tabular}{l|l|l}
\hline $\begin{array}{l}\text { Fluazifop-butyl } \\
\text { (Fusilade DX) 2 EC }\end{array}$ & $\begin{array}{l}\text { Apply before grasses are at a specific growth } \\
\text { stage. (Refer to label.) Do not harvest pecans } \\
\text { within 30 days of application. }\end{array}$ \\
\hline
\end{tabular}

Weeds Controlled and Remarks: Certain annual and perennial grasses. Use with a crop oil or nonionic surfactant (see label). May be used for site preparation. Repeat applications may be needed to control perennial grasses. Do not graze animals on any treated area. Limited to 72 oz per acre per year.

\begin{tabular}{|l|l|l|}
\hline $\begin{array}{l}\text { Glufosinate } \\
\text { (Rely) 1SL }\end{array}$ & 0.75 to 1.5 & $\begin{array}{l}\text { Do not apply to trees planted in the orchard } \\
\text { for less than one year. }\end{array}$ \\
\hline
\end{tabular}

Weeds Controlled and Remarks: Do not allow spray to contact green bark or foliage. Apply with a minimum spray volume of $20 \mathrm{gpa}$. Control of perennial weeds may require repeat applications. Can be tank mixed with certain pre-emergence herbicides (see label).

\begin{tabular}{|l|l|l|}
\hline $\begin{array}{l}\text { Glyphosate } \\
\text { (Various) }\end{array}$ & 1 to 2 & $\begin{array}{l}\text { See label for specific application timings and } \\
\text { rates. }\end{array}$ \\
\hline
\end{tabular}

Weeds Controlled and Remarks: Post-emergence activity only. Damages all green tissue contacted. Has no effective residual activity in soil. Rate used depends on weed species to be controlled. Do not allow contact of spray, drift or mist with green foliage, exposed roots, green bark or bark of trees established less than 2 years. Do not feed or forage treated crops within 8 wks. after application. See label for preharvest interval and restrictions on application equipment.

\begin{tabular}{|l|l|l|}
\hline $\begin{array}{l}\text { Paraquat } \\
\text { (Various) }\end{array}$ & 0.66 to 1 & $\begin{array}{l}\text { Apply to weeds when succulent and is 1-6" } \\
\text { high. }\end{array}$
\end{tabular}

Weeds Controlled and Remarks: Controls most annual grass and broadleaf weeds. Perennial weeds are desiccated. Use a non-ionic surfactant (see label). Do not allow spray to contact green stems, nuts or foliage. Do not spray under windy conditions and use a shield for young trees. May be tank mixed with certain pre-emergence herbicides. Do not graze on treated areas. Do not apply when nuts to be harvested are on the ground. 
Table 1. Chemical weed control in pecans.

\begin{tabular}{|l|l|l|}
\hline $\begin{array}{l}\text { Sethoxydim } \\
\text { (Poast) } 1.5 \text { EC }\end{array}$ & $\begin{array}{l}0.19 \text { to } 0.47 \\
\begin{array}{l}\text { Apply to actively growing grasses. See label } \\
\text { for specific timings and rates. Do not apply } \\
\text { within 15 days of harvest. }\end{array}\end{array}$ \\
\hline
\end{tabular}

Weeds Controlled and Remarks: Controls most annual and perennial grasses. Rate depends on type of grass to be controlled. Repeat applications may be needed to control perennial grasses. Do not apply more than 10 pt. per acre per year. See label for information on additives that increase herbicidal activity.

\begin{tabular}{|l|l|l|}
\hline $\begin{array}{l}\text { 2, 4-D amine } \\
\text { (Various) }\end{array}$ & 0.95 to 1.4 & $\begin{array}{l}\text { Apply during growing season except during } \\
\text { bloom, to activity growing broadleaf weeds. } \\
\text { Do not treat within } 60 \text { days of harvest. }\end{array}$ \\
\hline
\end{tabular}

Weeds Controlled and Remarks: Do not make more than 2 applications per year. Do not apply to trees established for less than one year. Refer to product labels for specifications on application rates and timings.

\begin{tabular}{|c|c|c|}
\hline \multicolumn{3}{|c|}{ Post-emergence - non-bearing only } \\
\hline $\begin{array}{l}\text { Common Name } \\
\text { (Trade name) }\end{array}$ & $\begin{array}{l}\text { Pounds active ingredient } \\
\text { per acre }\end{array}$ & Time of Application \\
\hline $\begin{array}{l}\text { Clethodim } \\
\text { (Arrow, Intensity or } \\
\text { Select) } 2 \mathrm{EC} \\
\text { (SlectMax or Intensity } \\
\text { One) 1EC }\end{array}$ & 0.094 to 0.125 & $\begin{array}{l}\text { Nonbearing trees only. Avoid contact of spray } \\
\text { with crop foliage. }\end{array}$ \\
\hline \multicolumn{3}{|c|}{$\begin{array}{l}\text { Weeds Controlled and Remarks: Apply to actively growing grasses not under stress. See label for rate } \\
\text { and optimum grass size to treat. Use non-ionic surfactant (see label). }\end{array}$} \\
\hline $\begin{array}{l}\text { Flumioxazin } \\
\text { (Chateau) } 51 \text { WDG }\end{array}$ & 0.19 to 0.38 & Nonbearing trees only. \\
\hline \multicolumn{3}{|c|}{$\begin{array}{l}\text { Weeds Controlled and Remarks: Controls most annual broadleaf and grass weeds and some perennials. } \\
\text { Apply to non-bearing trees only. Trees established for less than one year should be shielded from contact } \\
\text { with spray solution. Do not exceed } 6 \text { oz per acre per year to trees established less than } 3 \text { years in soils } \\
\text { having a sand plus gravel content of more than } 80 \% \text {. Do not tank mix with glyphosate or } 2,4-D \text { amine after } \\
\text { trees break dormancy. }\end{array}$} \\
\hline
\end{tabular}

